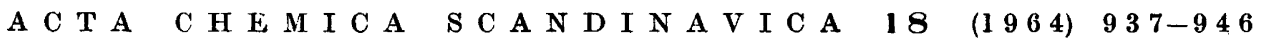

\title{
The Adenosine Triphosphate Contents of the Mucosa and the Entire Wall of the Alimentary Tract of the Rat and the Activities of the Enzyme System Hydrolyzing ATP in the Alimentary Tract Mucosa of the Rat During the Absorption of Nutrients
}

\author{
O. H Ä N N INEN, K. HART IALA and V. NURMIKKO
}

Department of Physiology and Department of Biochemistry, University of Turku, Finland

The contents of adenosine triphosphate (ATP) in the mucosae and walls in different parts of the alimentary tract and the activities of the enzyme system hydrolyzing ATP in mucosa homogenates have been determined. The contents in the liver and, in some cases, also in the abdominal rectus muscle were determined for comparison.

The liver was found to contain 1.80-4.17 $\mu$ moles of ATP/g of dry weight $(19.1-56.3 \mu$ moles of ATP/g of ammonia-N) in different series of experiments. The membranous part of the stomach wall contained slightly more than one third of the amount of ATP in the mucosa of the oral part of the small intestine. The glandular stomach mucosa contained about the same amount of the compound as the oral end of the small intestine, where the content was $1.05 \mu$ moles of ATP/g of dry weight $(9.93 \mu$ moles/g of ammonia $N)$. Samples of the entire wall from the first $5 \mathrm{~cm}$ of the small intestine contained 4.85 $\mu$ moles of ATP/g of dry weight (49.7 $\mu$ moles/g of ammonia N). Further along the small intestine the content of ATP decreased both in the mucosa and in the entire wall. This decrease was not linear, but clearly more rapid in the oral than in the aboral part of the intestine. In the investigations the ATP content of the appendix was of the same order as the content in the lower end of the small intestine and the ATP content of the entire wall of the large intestine was nearly equal to the contents in the upper end of the small intestine.

The activity of the enzyme system in the liver was about half of the activity in the initial part of the small intestine. The enzyme activity in the stomach was about a fifth of that in the initial part of the small intestine; the enzyme activity decreased in a non-linear manner along the small intestine. The activity in the appendix and the large intestine was at the same level as in the lower end of the small intestine.

The rate of absorption of nutrients varies along the intestine ${ }^{1-6}$ as also, for 1 instance, the synthesis of $\beta$-D-glucopyranosiduronic acids. ${ }^{7}$ In contrast to these processes which consume energy, cell material is synthesized - cells are regenerated - at about the same rate in all parts of the small intestine. ${ }^{8}$ 
The ATP contents in different parts of the alimentary canal of different animals have been studied previously ${ }^{9-15}$ as have also the changes occurring in ATP content in different absorption processes. ${ }^{10,16}$

In our present study the ATP contents in different parts of the alimentary canal of male rats were determined during the process of digestion-absorption both by taking specimens of the mucous membrane and whole wall. Specimens from the liver and the abdominal rectus muscle were also studied for comparison.

In order to find out at what rate adenosine triphosphate is metabolized in different parts of the alimentary tract of the rat, the rates at which ATP is hydrolyzed in homogenates of the mucosae were determined. The "adenosine triphosphatase" activity in intestinal mucosa has been studied by Hele, ${ }^{17}$ Luithy and Verzar, ${ }^{18}$ Pereira, ${ }^{19}$ Fehér et $a l .{ }^{10}$ and by Kertai et $a l .{ }^{20}$, but their studies were not systematic.

\section{EXPERIMENTAL}

Test animals. Male Wistar-rats were employed in the study. The diet is described in a following paper by Hänninen and Hartiala. ${ }^{21}$ Experiments began $5-6 \mathrm{~h}$ after feeding. The weights of the animals were $140-180 \mathrm{~g}$ in the ATP content determinations and $200-300 \mathrm{~g}$ in the study of the enzyme system hydrolyzing ATP.

Preparation of samples. (a) The ATP determinations. After the rat had been anaesthesized with ether in a glass vessel the abdominal cavity was opened with scissors along the mid-line; the connective tissues attached to the membranous part of the stomach were cut off to free the stomach. A string was fastened to the tail and lightly around the neck - not to hamper the breathing of the animal - and the animal was dipped for 15 sec into a $\mathrm{CO}_{2}$-ice-ethanol bath. A liver fragment, the stomach, and the intestines were removed in a cold room $\left(0^{\circ} \mathrm{C}\right)$ and placed in a $0.25 \mathrm{M}$ sucrose solution at the freezing point. The alimentary canal was opened and, after its contents had been carefully removed with a brush, rinsed with $0.25 \mathrm{M}$ sucrose $\left(0^{\circ}\right)$. For the study of the mucosa, the latter was scraped off with a heat insulated ampoule file; from the intestinal specimens the mucosa was taken only from $1.5-\mathrm{cm}$ long sections in the central part. For the study of the whole wall, sections of the intestinal walls were taken. The samples were transferred to tared centrifuge tubes containing $2.0 \mathrm{ml}$ of water at $0^{\circ} \mathrm{C}$. The removal of samples from the animals was begun alternately at the upper and the lower ends of the alimentary tract. The sample preparation time was about $20 \mathrm{~min}$. Each sample was heated in the tube over an open gas flame for $10 \mathrm{sec}$, after which the extraction was continued by placing the tube in a vigorously boiling water bath for $5 \mathrm{~min}$. After the extraction, the tube was immersed in an ice bath. The denaturated protein was removed by centrifuging $(6000 \mathrm{rpm}$ for $15 \mathrm{~min}$ at $20^{\circ}$ ). The extracts of the small intestine remained turbid, however. The precipitate was employed in the determination of dry weight (after at least $8 \mathrm{~h}$ in an oven at $92^{\circ} \mathrm{C}$ ) and ammonia N (modified Kjeldahl). The ATP content of the supernatant was determined immediately after the extraction.

(b) Activities of the enzyme system hydrolyzing ATP. The stomach, the intestines. and part of the liver were removed from the anaesthetized animal at a temperature of $4^{\circ}$ and were placed in physiological $\mathrm{NaCl}$ solution at $4^{\circ}$. The alimentary tract was excised, and its contents were removed carefully with a brush and a physiological NaCl solution $\left(4^{\circ}\right)$. The mucous membrane was scraped with an ampoule file; the samples were homogenized, first 15 sec in a metal (Ultra-Turrax) homogeniser and then a further 30 sec in an all-glass Potter-Elvehjem type of homogeniser. Samples of the homogenates were taken for the determination of dry weight and ammonia N. Before the ATP determinations the homogenates were preserved at $4^{\circ}$ for $18-20 \mathrm{~h}$. The technique of scraping the mucosa was studied histologically.

Points from which specimens were taken. Specimens were taken from (1) The liver (part of the lobe visible below the left arch), (2) the membranous part of the stomach, (3) the lesser curvature, (4) the greater curvature, (5) the antral part of the stomach, 
(6) the first $5-\mathrm{cm}$ section of the small intestine, $(7-10)$ successive $10 \mathrm{~cm}$ lengths of the small intestine, (11) the fifth last $10-\mathrm{cm}$ section, (12) the third last 10-cm section, (13) the last 10-cm section of the small intestine, (14) the appendix, (15) the first $3 \frac{1}{2} \mathrm{~cm}$ of the large intestine, (16) the last $3 \frac{1}{2} \mathrm{~cm}$ of the large intestine. - Peyer's spots were avoided as far as possible. - Samples were also taken from the abdominal rectus muscles of some of the animals.

$A T P$ determinations. The methods of Strehler and Totter ${ }^{22}$ and Strehler and McElroy ${ }^{23}$ were modified as follows. Live-desiccated firefly tails (Sigma Chemical Co.) were homogenized and extracted with an $0.1 \mathrm{M}$ arsenate buffer of $\mathrm{pH} 7.4\left(1 \frac{1}{2}\right.$ tails $\left./ \mathrm{ml}\right)$ in an icebath for $10 \mathrm{~min} ; 10 \mathrm{mg} \mathrm{MgSO} \mathrm{MH}_{4} \cdot 7 \mathrm{H}_{2} \mathrm{O}$ per ml of buffer was added and the extract was centrifuged at $4000 \mathrm{rpm}$ for $10 \mathrm{~min}$ at $4^{\circ}$. The supernatant was set apart and preserved in an ice-bath overnight. The slight precipitate was centrifuged down and the supernatant was employed in the ATP determinations. A $0.200 \mathrm{ml}$ volume of tissue extract or of ATP standard $\left(0.5-10 \times 10^{-3} \mu\right.$ moles) (Sigma Chemical Co.) (about 20 $0^{\circ}$ was added to a $0.5 \mathrm{ml}$ cuvette containing $0.200 \mathrm{ml}$ of the firefly preparation $\left(0^{\circ}\right)$. After $30 \mathrm{sec}$ the intensity of light ( $\mathrm{T} \%$ ) was measured with a Beckman DU spectrophotometer fitted with a photomultiplier tube. Because some tissue extracts were not clear, a known amount of ATP was added to each of the samples after three parallel determinations and the absorbances of the samples were remeasured. Recovery values for samples from different portions of the intestine were typical for each portion. Parallel determinations differed less than $5 \%$ from the mean.

Determination of the activity of the enzyme system hydrolyzing ATP. When the dry weight had been determined, the homogenates were diluted with water to a concentration of $2 \mathrm{mg}$ dry weight/ml. Centrifuge tubes containing $0.050 \mathrm{ml}$ of buffer substrate solution (15 mM ATP, $15 \mathrm{mM}$ tris (hydroxymethyl) aminomethane, $3 \mathrm{mM} \mathrm{MgCl}$, pH 8.4 (HCl) and $0.100 \mathrm{ml}$ of the homogenate dilution were incubated in a water bath at $38^{\circ}$ for $15 \mathrm{~min}$. The reaction was stopped by placing the tube in an ice bath and adding $0.010 \mathrm{ml}$ of $45 \%$ trichloroacetic acid. The protein was precipitated by centrifugation $(5000 \mathrm{rpm}$ for $10-$ $15 \mathrm{~min}$ ) and $2.0 \mathrm{ml}$ of $\mathrm{H}_{2} \mathrm{O}$ was added to the supernatant, after which the same volume was withdrawn for the phosphate determination. ${ }^{24}$ The volumes were made up to $2.5 \mathrm{ml}$ with distilled water and $0.5 \mathrm{ml}$ of $3.0 \mathrm{~N} \mathrm{H}_{2} \mathrm{SO}_{4}, 1.5 \%$ ammonium molybdate (dissolved in water) solution. A blue color was developed by adding $0.025 \mathrm{ml}$ of a reducing reagent (prepared by dissolving $250 \mathrm{mg}$ of reducing reagent powder in $8.33 \mathrm{ml}$ of water $\left(0^{\circ}\right)$ ). The absorbance at $660 \mathrm{~m} \mu$ was measured after $600 \pm 5$ sec. - Three parallel enzyme activity determinations were made on each tissue homogenate.

\section{RESULTS}

ATP contents in the alimentary canal wall. The stability of adenosine triphosphate under the extraction conditions was controlled by subjecting solutions containing known amounts of ATP to the same treatment and following the changes in ATP concentration during the various phases of the extraction. A total loss of about $4.4 \%$ occurred during the entire procedure.

To study possible losses of ATP into the two solvents used for the withdrawal of samples, the cold mixture $(1100 \mathrm{ml})$ was evaporated in vacuo after the usual cold treatment. The same was done with the water $(50 \mathrm{ml})$ which had been substituted for the $0.25 \mathrm{M}$ sucrose rinsing solution. The residues were dissolved in small volumes of water and analysed for ATP. No ATP was found in the water, but the cold mixture contained about $10^{-4} \mu$ mole. However, fairly large amounts of ATP disappear from the tissues, for when the time during which a sample of the abdominal rectus muscle was kept in the cold mixture was increased from 15 sec to $15-30 \mathrm{~min}$, the ATP concentration decreased to about one half.

The effectiveness of hot water extraction was also tested; successive identical extractions were made on samples of abdominal rectus muscle, and the

Acta Chem. Scand. 18 (1964) No. 4 
Table 1. ATP contents of mucosa samples from the alimentary canal. The mean contents (and standard errors) were calculated per gram of dry weight and per gram of ammonia nitrogen. The relative contents were calculated taking the content in sample No. 6 as unity.

\begin{tabular}{|c|c|c|c|c|}
\hline \multirow[b]{2}{*}{ Sample } & \multicolumn{2}{|c|}{ ATP content } & \multicolumn{2}{|c|}{ Relative content } \\
\hline & $\begin{array}{l}\mu \text { moles/g of } \\
\text { dry weight }\end{array}$ & $\begin{array}{l}\mu \text { moles } / g \\
\text { of } \mathrm{NH}_{4} \cdot \mathrm{N}\end{array}$ & ATP/dry weight & $\mathrm{ATP} / \mathrm{NH}_{4}-\mathrm{N}$ \\
\hline 1 & 1.80 土 0.59 & $19.1 \pm 5.3$ & 1.72 & 1.92 \\
\hline 2 & $0.374 \pm 0.068$ & $2.94 \pm 0.83$ & 0.36 & 0.30 \\
\hline 3 & $1.11 \pm 0.19$ & $7.76 \pm 0.91$ & 1.06 & 0.78 \\
\hline 4 & $0.854 \pm 0.24$ & $6.84 \pm 1.8$ & 0.81 & 0.69 \\
\hline 5 & $0.892 \pm 0.089$ & $6.73 \pm 0.93$ & 0.85 & 0.68 \\
\hline 6 & $1.05 \pm 0.121$ & $9.93 \pm 1.2$ & 1 & 1 \\
\hline 7 & $0.853 \pm 0.11$ & $7.14 \pm 0.95$ & 0.81 & 0.72 \\
\hline 8 & $0.693 \pm 0.18$ & $6.81 \pm 1.5$ & 0.65 & 0.68 \\
\hline 9 & $0.554 \pm 0.15$ & $5.09 \pm 1.3$ & 0.53 & 0.51 \\
\hline 10 & $0.488 \pm 0.15$ & $4.70 \pm 1.4$ & 0.47 & 0.47 \\
\hline 11 & $0.406 \pm 0.086$ & $3.50 \pm 0.69$ & 0.39 & 0.35 \\
\hline 12 & $0.391 \pm 0.078$ & $3.40 \pm 0.60$ & 0.37 & 0.34 \\
\hline 13 & $0.452 \pm 0.093$ & $3.86 \pm 0.84$ & 0.43 & 0.39 \\
\hline 14 & $0.335 \pm 0.050$ & $2.86 \pm 0.50$ & 0.32 & 0.29 \\
\hline 15 & $0.051 \pm 0.049$ & $4.38 \pm 0.47$ & 0.48 & 0.44 \\
\hline 16 & $0.912 \pm 0.15$ & $8.04 \pm 1.1$ & 0.87 & 0.81 \\
\hline
\end{tabular}

supernatant was removed after each extraction. The mean value obtained in three parallel tests were $83.5 \%$ (range 80.5-88.5) for the first extraction, $13.9 \%(11.5-16.4)$ for the second, and $2.5 \%$ for the third.

$A T P$ of the mucous membranes. Ten animals were studied. As seen from Table 1, the liver samples contained $1.80 \mu$ moles of ATP/g of dry weight. A sample cut from the outer edge of the lobe contained less ATP than a sample cut from a deeper part of the lobe. For this reason the liver samples studied later were taken from deeper layers.

As regards the stomach, the ATP concentration was lowest in samples from the membranous part. The lesser curvature and the antral area of the glandular

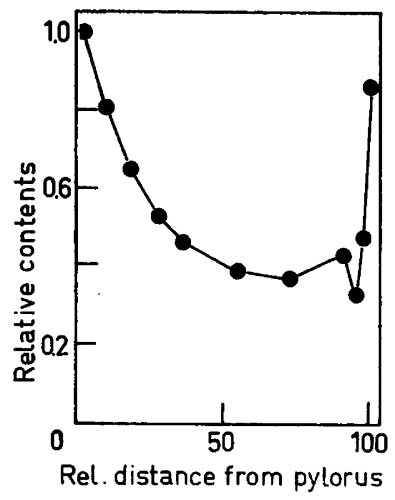

Fig. 1. Relative ATP content (calculated on a dry weight basis) of the intestinal mucosa as a function of the length of the intestine with the content of sample No. 6 equal to unity. The length of the intestine from the pylorus to the anus is taken as $\mathbf{1 0 0}$. 
stomach contained somewhat more ATP than the greater curvature. In general the ATP concentrations were of the same order as in the oral end of the small intestine.

The average ATP contents in the first $5 \mathrm{~cm}$ of the small intestine was $1.05 \mu$ moles/g dry weight. The ATP content decreased along the next $35 \mathrm{~cm}$ of the small intestine to about half the content in the first $5 \mathrm{~cm}$ of the intestine (Fig. 1). After this decrease the ATP content remained practically constant. The ATP content of the appendix was about a third, and that in the first $3 \frac{1}{2} \mathrm{~cm}$ of the large intestine about half the content in the first part of the small intestine. In the last $3 \frac{1}{2} \mathrm{~cm}$ of the large intestine, however, the ATP content was almost the same as in the oral end of the small intestine.

ATP of the entire wall. Five rats were studied. Table 2 shows that the liver samples from these animals contained about $4 \mu$ moles of ATP/g of dry weight. No sample was cut from the edge of the lobe. The lowest ATP content in the stomach next to the membranous part was again found in the greater curvature. At the oral end of the small intestine the ATP concentration was 4.8-4.9 $\mu$ moles/g of dry weight; this content is markedly higher than any recorded in the investigation of the mucous membrane, higher even than the content in the liver samples. The ATP content decreased rapidly along the first $40 \mathrm{~cm}$ of the small intestine but decreased only slowly along the remaining part of the small intestine. The ATP content of the appendix was close to that in the last part of the small intestine. In the large intestine the ATP content increased until it reached the level in the oral end of the small intestine.

Table 2. ATP contents of entire wall samples from the alimentary canal. The mean contents (and standard errors) were calculated per gram of dry weight and per gram of ammonia nitrogen. The relative contents were calculated taking the content in sample No. 6 to be unity.

\begin{tabular}{|c|c|c|c|c|}
\hline \multirow[b]{2}{*}{ Sample } & \multicolumn{2}{|c|}{ ATP content } & \multicolumn{2}{|c|}{ Relative content } \\
\hline & $\begin{array}{l}\mu \text { moles/g of } \\
\text { dry weight }\end{array}$ & $\begin{array}{l}\mu \text { moles } / g \\
\text { of } \mathrm{NH}_{4}-\mathrm{N}\end{array}$ & ATP/dry weight & $\mathrm{ATP} / \mathrm{NH}_{4}-\mathrm{N}$ \\
\hline 1 & $4.17 \pm 0.99$ & $56.3 \pm 11.5$ & 0.86 & 1.13 \\
\hline 2 & $0.292 \pm 0.040$ & $2.76 \pm 0.35$ & 0.060 & 0.056 \\
\hline 3 & $2.44 \pm 0.52$ & $17.9 \pm 3.6$ & 0.50 & 0.36 \\
\hline 4 & $0.534 \pm 0.078$ & $4.41 \pm 0.63$ & 0.11 & 0.09 \\
\hline 5 & $3.14 \pm 0.83$ & $16.6 \pm 4.3$ & 0.65 & 0.33 \\
\hline 6 & $4.85 \pm 0.50$ & $49.7 \pm 7.0$ & 1 & 1 \\
\hline 7 & $4.92 \pm 0.96$ & $42.6 \pm 7.8$ & 1.01 & 0.96 \\
\hline 8 & $3.76 \pm 0.73$ & 32.0 士 5.7 & 0.78 & 0.64 \\
\hline 9 & $2.71 \pm 0.54$ & $24.3 \pm 4.9$ & 0.56 & 0.49 \\
\hline 10 & $1.50 \pm \mathbf{0 . 4 5}$ & $13.8 \pm 3.9$ & 0.31 & 0.28 \\
\hline 11 & $0.860 \pm 0.30$ & $8.18 \pm 2.7$ & 0.18 & 0.18 \\
\hline 12 & $0.486 \pm 0.11$ & $4.72 \pm 0.94$ & 0.10 & 0.090 \\
\hline 13 & $0.656 \pm 0.18$ & $6.44 \pm 1.8$ & 0.14 & 0.13 \\
\hline 14 & $0.488 \pm 0.062$ & $5.05 \pm 0.88$ & 0.10 & 0.10 \\
\hline 15 & $2.93 \pm 0.68$ & $24.5 \pm 5.1$ & 0.60 & 0.49 \\
\hline 16 & $4.76 \pm 1.27$ & $39.7 \pm 10.0$ & 0.98 & 0.80 \\
\hline
\end{tabular}

Acta Chem. Scand. 18 (1964) No. 4 
The skeletal muscle. Samples of skeletal muscle taken from the abdominal rectus muscles of five animals contained on average: $10.5 \mu$ moles of ATP/g of dry weight, or $66.4 \mu$ moles/g ammonia $\mathrm{N}$. The extracts of the muscles were clear.

Activities of the enzyme system hydrolyzing ATP in the alimentary canal mucosa. The activity of the enzyme system was well maintained during the storage at $4^{\circ}$. The activity in the undiluted liver and duodenal mucosa homogenates was found to be the same after $30 \mathrm{~min}$ as after $18 \mathrm{~h}$. The liberation of phosphate progressed linearly with time in the activity tests.

For a control of the phosphate determination, a known amount of phosphate was added to a number of incubated and unincubated reaction mixtures. In both cases the average recovery was about the same, $98 \%$ (range $95-$ $102 \%)$.

Ion-exchange chromatography (a modification of the method of Hurlbert et $a l .{ }^{25}$ ) revealed that adenosine diphosphate (ADP) was not the only reaction product; the reactions went further, and in addition to some adenosine monophosphate other derivatives were detected.

Table 3 shows that the activity of the enzyme system hydrolyzing ATP in the liver samples of the studied ten animals was slightly greater than half the activity in the mucous membrane from the upper end of the small intestine.

In stomach the enzyme activity proved to be the highest in the membranous part although the activity was only about a fourth of the activity in the first $5 \mathrm{~cm}$ of the small intestine. The next highest activity was found in the greater curvature.

Table 3. Activities of the enzyme system hydrolyzing ATP in mucosa samples from the alimentary canal. The mean activities (and standard errors) were calculated relative to dry weight and $\mathrm{NH}_{4}-\mathrm{N}$. The relative activities were calculated taking the activity of sample No. 6 to be unity.

\begin{tabular}{|c|c|c|c|c|}
\hline \multirow[b]{2}{*}{ Sample } & \multicolumn{2}{|c|}{ Phosphate liberated } & \multicolumn{2}{|c|}{ Relative activity } \\
\hline & $\begin{array}{c}\mu \mathrm{moles} / \mathrm{mg} \\
\times \quad 15 \mathrm{~min} / \mathrm{g} \text { of } \\
\text { dry weight }\end{array}$ & $\begin{array}{c}\mu \text { moles } / \mathrm{mg} \\
\times \quad 15 \mathrm{~min} / \mathrm{g} \\
\text { of } \mathrm{NH}_{4}-\mathrm{N}\end{array}$ & dry weight & $\mathrm{NH}_{4} \cdot \mathrm{N}$ \\
\hline 1 & $1.76 \pm 0.92$ & $24.1 \pm 1.22$ & 0.53 & 0.62 \\
\hline 2 & $0.78 \pm 0.082$ & $9.38 \pm 0.92$ & 0.24 & 0.24 \\
\hline 3 & $0.47 \pm 0.075$ & $6.65 \pm 0.78$ & 0.14 & 0.14 \\
\hline 4 & $0.66 \pm 0.12$ & $8.93 \pm 1.09$ & 0.20 & 0.23 \\
\hline 5 & $0.53 \pm 0.052$ & $4.49 \pm 0.63$ & 0.16 & 0.11 \\
\hline 6 & $3.32 \pm 0.12$ & $39.9 \pm 2.33$ & 1 & 1 \\
\hline 7 & $2.77 \pm 0.099$ & $31.1 \pm 1.12$ & 0.83 & 0.78 \\
\hline 8 & $2.34 \pm 0.084$ & $27.4 \pm 1.65$ & 0.70 & 0.69 \\
\hline 9 & $2.28+0.10$ & $24.9 \pm 1.66$ & 0.69 & 0.69 \\
\hline 10 & $2.00 \pm 0.17$ & $22.9 \pm 1.69$ & 0.60 & 0.57 \\
\hline 11 & $1.38 \pm 0.11$ & $19.9 \pm 2.41$ & 0.42 & 0.51 \\
\hline 12 & $0.99 \pm 0.078$ & $9.84 \pm 1.13$ & 0.30 & 0.25 \\
\hline 13 & $0.77 \pm 0.053$ & $8.51 \pm 0.80$ & 0.23 & 0.22 \\
\hline 14 & $0.68 \pm 0.055$ & $6.95 \pm 0.81$ & 0.21 & 0.18 \\
\hline 15 & $0.58 \pm 0.032$ & $6.83 \pm 0.81$ & 0.17 & 0.17 \\
\hline 16 & $0.61 \pm 0.064$ & $5.68 \pm 0.59$ & 0.18 & 0.15 \\
\hline
\end{tabular}


Fig. 2. Relative activities (calculated on a dry weight basis) of the enzyme system hydrolyzing ATP in the intestinal mucosa with the activity of sample No. 6 equal to unity. The length of the intestine from the pylorus to the anus is taken as 100 .

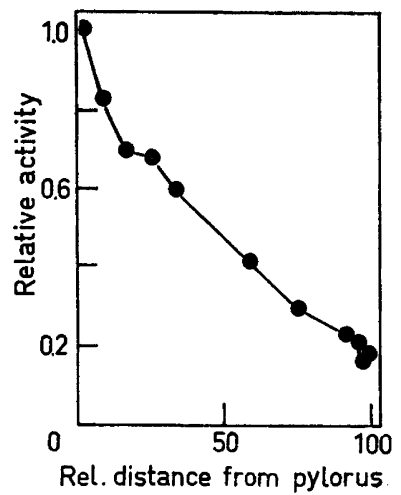

The highest activity in the small intestine was observed in the sample from the first $5 \mathrm{~cm}$; the activity of the enzyme system decreased in the other samples, but the decrease was not linear, as seen in Fig. 2. The activity of the enzyme system at the end of the small intestine was only slightly more than a fifth of the activity in the first $5 \mathrm{~cm}$ of the intestine. The enzyme activity in the large intestine was nearly the same as in the lower end of the small intestine, and was of the same order as in the appendix.

The relationships between the samples were similar also when the ATP contents and the activities of the enzyme system were calculated relative to the ammonium nitrogen contents.

\section{DISCUSSION}

Previously, investigators have often employed acid hydrolysis in ATP determinations, and determined the liberated inorganic phosphate. In such treatment, however, certain phosphates of other nucleosides, creatine phosphate and certain sugar phosphates are also hydrolyzed, ${ }^{26}$ and the mucosa of the intestine is rich in all these. ${ }^{9,27,28}$ Employing the hydrolysis method, Feher et al. ${ }^{10}$ found the ATP present in the first $20 \mathrm{~cm}$ of the mucosa of the small intestine of rats to be about $0.6 \%$ of the dry weight during glucose digestion and somewhat lower during fasting. This value is about 10 times as high as the values obtained in the present investigations. Kroeger and Edwards, ${ }^{9}$ Kertai et al. ${ }^{16}$, and Gáti et al..$^{29}$ all obtained similar high values with the hydrolysis method. Some hydrolysis experiments made in connection with the present investigation, gave results calculated as ATP that were close to their values.

Rapid freezing of the samples or denaturation of hydrolyzing enzymes clearly preserves the ATP in the samples. ${ }^{13,30-32}$ According to Fehér et al. ${ }^{10}$, however, it does not matter whether the samples are frozen immediately or after their preparation.

Because of the experimental procedure employed, the ratio of ATP to ADP could not be controlled in our study. The employed procedure of freezing with a cold mixture has been used previously by, e.g., Nilsson ${ }^{33}$ and Maas. ${ }^{34}$ Gauthe- 
ron and Born ${ }^{35}$ observed losses of ATP due to congelation in their study of rat uterus muscle. It is possible that this hydrolysis of ATP due to cold contraction takes place in nonmuscular tissues, too. The ATP contents of skeletal muscle determined in this work, which are somewhat lower than earlier investigators have found,$^{36}$ may be low for this reason.

The content of ATP in the liver samples found in connection with the mucosa investigation is definitely lower than the values obtained in earlier investigations of the ATP content of the liver. The values obtained in the later part of this study are much closer to the values Maas ${ }^{34}$ reported (about $5.9 \mu$ moles/g of dry weight). Maas also froze the tissues, but he used ion exchange chromatography in the ATP determinations.

As the rats used in the studies of the mucosa and the entire wall weighed the same and the samples, except for the liver samples, were prepared in the same way, the dependence of the ATP contents of the liver samples on how the samples were taken may be due to one or more of the three factors. The ATP may pass into the cold mixture and the loss may be higher for the samples from the lobe edges. Secondly the possible ATP hydrolysis due to cold contraction can be more profound at lobe edges. The third possibility would be that different parts of the liver contain different amounts of ATP, the amount being lower at the edges of the lobe than in the deeper layers.

The samples of the mucosa of the glandular part of the stomach taken from near the great constrictor muscles contained more ATP than those taken from the greater curvature. On histological investigation they and also the samples from the large intestine were found to contain smooth muscle fibres. The ATP content of the entire wall of the stomach of rats is more than twice the content found by Yakushiji et al. ${ }^{11}$ in experiments with dogs. Spencer et al. ${ }^{15}$ found ATP about $0.3 \mu$ mole/g wet weight in the stomach tissue of an adult male.

The ATP content has been reported to be $26 \%$ higher in the first $20 \mathrm{~cm}$ of the mucosa of the small intestine than in the last $20 \mathrm{~cm} .{ }^{10}$ Keir and Davidson, ${ }^{12}$ who employed ion exchange chromatography, did not find any differences between the amounts of nucleotides in the mucosa of the small intestine and in the appendix of the rat. In our study of the mucosa the content of ATP was found to be twice as high in the first $5 \mathrm{~cm}$ of the small intestine as in the last $10 \mathrm{~cm}$. Dietrich and Friedland ${ }^{13}$ found the ATP content of the small intestine mucosa of rabbits to be clearly higher than we found in rats. Parsons ${ }^{14}$ studied rapidly frozen samples of the entire wall of the small intestine of rats by paper chromatographic methods of the samples. The ATP content calculated from his results was about $6.5 \mu \mathrm{moles} / \mathrm{g}$ of dry weight. Spencer et $a l .{ }^{15}$ studied eight wall samples from different parts of the small intestine of a rat but found no differences between these; the ATP content was $1 \mu$ mole $/ \mathrm{g}$ of wet weight in all samples. The values obtained in the present investigation were of this magnitude only at the upper end of the small intestine.

Born ${ }^{37}$ found $1.8 \mu$ moles of ATP/g fresh weight in guinea pig taenia muscle and Spencer et al..$^{15} 0.28 \mu$ moles in a human colon, but there is no earlier information on the content in the mucosa of the large intestine.

A difference in the activity of the enzyme system hydrolyzing ATP, was observed between the mucosae at the oral and aboral ends of the small intestine, which clearly exceeded the difference observed in rabbits by Pereira. ${ }^{19}$ 
On the other hand the results obtained by Fehér el al. ${ }^{10}$ with rats largely agree with ours. These investigators used calcium ion as an activator, and the $\mathrm{pH}$ of the buffer they employed was 7.4. The mitochondrial adenosine triphosphate is specifically activated ${ }^{38}$ by magnesium ion and the $\mathrm{pH}$ optimum is about $8.5 .^{39}$

The components of the enzyme system were not analyzed in this study. Most likely, the enzyme preparations contained also other ATP-consuming systems besides the mitochondrial adenosine triphosphatase. Also the hydrolysis of ATP went further than ADP (cf. Ref. ${ }^{40}$ ). According to Hele ${ }^{17}$ the "adenosine triphosphatase" of the intestine keeps well, an observation confirmed in the present study.

The finding that the enzyme system is more active in the mucosa of the greater curvature than in the mucosae of other parts of the glandular stomach, and also more active in the oral part of the small intestine than elsewhere in the intestines or even in the liver suggests that ATP must be more rapidly synthesized in these parts of the alimentary canal than in others to maintain a constant ATP concentration. On the other hand, a hypothesis had also been advanced according to which adenosine triphosphatase acts as a transferase in oxidative phosphorylation. ${ }^{41}$

ATP creates the required conditions for the biosynthesis of enzyme protein, mucus substance, products of detoxication, and general cell material, and, in addition, for the biosynthesis of hydrochloric acid in the glandular part of the stomach and for the processes by which nutrients are actively absorbed in the small intestine. The most effective absorption of glucose, galactose,$^{3,5}$ amino acids, lipids, ${ }^{1}$ water, ${ }^{42}$ and calcium ${ }^{2}$ takes place in the oral part of the small intestine. The efficiency of the absorption decreases along the small intestine..$^{2,3,5,43}$ The synthesis of $\beta$-D-glucopyranosiduronic acids is greatest in the duodenum and decreases along the intestine. ${ }^{7}$ The results obtained in the present study indicate that the decrease in activities of the processes as a function of the length of the intestine is due to limited energy supply. Yet neither the ATP content nor the activity of the enzyme system hydrolyzing ATP decrease in parallel with the absorption along the small intestine.

According to observations of Dorman and Steggerda ${ }^{43}$ the rate at which oxygen is consumed in the small intestine of a cat slows down linearly as a function of the length of the small intestine.

Our observation that the whole wall contained more ATP than the mucous membrane agrees with the results obtained by Kroeger and Edwards, ${ }^{9}$ but Fehér et al.10 found the opposite. The difference in the ATP contents of the entire wall and the mucosa does not necessarily mean, however, that the muscle in the wall contains more ATP than the mucosa, because, according to the histological investigation, a part of the deepest layers of mucosa in which cell regeneration mainly occurs, ${ }^{8}$ remained attached to the so-called muscle layer when the mucosa was scraped; it is also probable that these deeper layers were not removed to the same extent with the mucosa samples from the oral end of the small intestine as with the other mucosa samples. The results may, however, be said to confirm the pacemaker character of the upper part of the small intestine. ${ }^{44}$ 
Acknowledgement. This study has been supported by a grant from the Sigrid Jusélius Foundation.

\section{REFERENCES}

1. Borgström, B., Dahlquist, A., Lundh, G. and Sjövall, J. J. Clin. Invest. 36 (1957) 1521.

2. Shacter, D. and Rosen, S. M. Am. J. Physiol. 196 (1959) 357.

3. Crane, R. K. and Mandelstam, P. Biochim. Biophys. Acta 45 (1960) 460.

4. Spencer, R. P. and Samiy, A. H. Federation Proc. 19 (1960) 183.

5. Baker, R. D., Searle, G. W. and Nunn, A. S. Am. J. Physiol. 200 (1961) 301.

6. Barry, B. A., Mathews, J. and Smyth, D. H. J. Physiol. 157 (1961) 279.

7. Hartiala, K. Unpublished observations 1963.

8. Bertalanffy, F. D. Acta Anat. 40 (1960) 130.

9. Kroeger, D. C. and Edwards, L. D. J. Am. Pharm. Assoc. 42 (1953) 560.

10. Fehér, I., Kertai, P. and Gáti, T. Acta Physiol. Acad. Sci. Hung. 10 (1956) 19.

11. Yakushiji, T., Kikuchi, T., Yamamoto, J. and Kuriaki, K. Am. J. Physiol. 192 (1958) 476.

12. Keir, H. M. and Davidson, J. N. Arch. Biochem. Biophys. 77 (1958) 68

13. Dietrich, L S. and Friedland, I. M. Proc. Soc. Exptl. Biol. Med. 101 (1959) 470.

14. Parsons, B. J. J. Physiol. 148 (1959) 117.

15. Spencer, R. P., Brody, K. R. and Bow, T. M. Gastroenterology 44 (1963) 282.

16. Kertai, P., Fehér, I. and Gáti, T. Acta Physiol. Acad. Sci. Hung. 10 (1956 b) 33.

17. Hele, M. P. Biochem. J. 55 (1953) 857.

18. Lüthy, E. and Verzar, F. Biochem. J. 57 (1954) 316.

19. Pereira, F. B. Comt. Rend. Soc. Biol. 149 (1955) 430.

20. Kertai, P., Gáti, T., Fehér, I., Harmon, G. and Kocsis, F. Acta Physiol. Acad. Sci. Hung. 9 (1956 a) 285.

21. Hänninen, O. and Hartiala, K. Acta Chem. Scand. 18 (1964) 947.

22. Strehler, B. L. and Totter, J. R. Arch. Biochem. Biophys. 40 (1952) 28.

23. Strehler, B. L. and MeElroy, W. D. in Colowick, S. P. and Kaplan, N. O. Methods in Enzymology. Vol. III, Acad. Press, N.Y. 1957, No. 122.

24. Fiske, C. H. and Subbarow, Y. J. Biol. Chem. 66 (1925) 375 and references in Colowick, S. P. and Kaplan, N. O. Methods in Enzymology. Vol. III, Acad. Press, N. Y. 1957, p. 843.

25. Hurlbert, R. B., Schmitz, H., Brumm, A. F. and Potter, V. R. J. Biol. Chem. 209 (1954) 23.

26. Netter, H. Theoretische Biochemie, Springer Verlag, Berlin 1959, p. 491.

27. Kjerulf-Jensen, K. Acta Physiol. Scand. 4 (1942) 225.

28. Daoust, R. and Cantero, A. Cancer Res. 15 (1955) 734.

29. Gáti, T., Harmon, G. and Ludany, G. Arch. Intern. Pharmakodynamie 114 (1958) 251.

30. Tsuyuki, H. and Idler, D. R. J. Am. Chem. Soc. 79 (1957) 771.

31. Henderson, J. F. and LePage, G. A. Chem. Rev. 58 (1958) 650.

32. Tsuboi, K. K. Arch. Biochem. Biophys. 83 (1959) 445.

33. Nilsson, R. Acta Chem. Scand. 11 (1957) 1003.

34. Maas, H. Z. ges. exptl. Med. 133 (1960) 971.

35. Gautheron, D. and Born, G. V. R. Biochim. Biophys. Acta 27 (1958) 580.

36. Jordan, W. J. and Gray, I. J. Biol. Chem. 215 (1955) 669.

37. Born, G. V. R. J. Physiol. 131 (1956) 704.

38. Kielley, W. W. and Kielley, R. K. J. Biol. Chem. 200 (1953) 213.

39. Kielley, W. W. in Boyer, P. D., Lardy, H. and Myrbäck, K. The Enzymes Vol. V, Acad. Press, N. Y. 1961, p. 149.

40. Wilson, T. H. Intestinal Absorption, Saunders Co, Philadelphia 1962, p. 202.

41. Lardy, H. A. in McElroy, W. D. and Glass, B. Phosphorus Metabolism. Vol. II, John Hopkins Press, Baltimore 1951, p. 477.

42. Smyth, D. H. and Taylor, C. B. J. Physiol. 136 (1957) 632.

43. Dorman, H. L. and Steggerda, F. R. Am. J. Physiol. 201 (1961) 292.

44. Hasselbrack, R. and Thomas, J. E. Federation Proc. 20 (1961) 246.

Received December 30, 1963.

Acta Chem. Scand. 18 (1964) No. 4 